\title{
Six new species of coffee (Coffea) from northern Madagascar
}

\author{
Aaron P. Davis ${ }^{1}$ [D \& Franck Rakotonasolo ${ }^{2,3}$
}

Summary. Six new species of Coffea are described as new to science: Coffea callmanderi, C. darainensis, C. kalobinonensis, C. microdubardii, C. pustulata and C. rupicola. All six species are endemic to northern Madagascar; four species are narrowly endemic to specific forest areas. Associated information, including distribution maps, conservation assessments, phenology and taxonomic notes are provided, and two species are illustrated with line drawings.

Key Words. conservation, IUCN Red List Categories, mountain flora, Rubiaceae, taxonomy.

\section{Introduction}

Madagascar is home to 59 species of Coffea L. (Davis et al. 2006; Davis \& Rakotonasolo 2008; Davis et al. 2010), which is nearly half of the 124 known to exist in the world (Davis et al. 2019). The 65 other Coffea species are found in Africa (48 species), the Comoros islands (one species), Mascarene Islands (three species; although a fourth (C. bernardiniana J.-F.Leroy) is sometimes recognised), Indian subcontinent and Sri Lanka (six species), south tropical Asia (two species), south-eastern Asia (four species) and Australasia (one species) (Davis 2011; Davis et al. 2011, 2019).

Starting in 2003, a series of field expeditions were conducted to explore the flora and vegetation in a long-neglected region of low to high elevation humid forest in northern Madagascar (Callmander et al. 2018) and the north-western Daraina area, which is located at the crossroads of four main phytogeographic units and possesses a variety of forest types (Gautier et al. 2006; Nusbaumer et al. 2010). Despite the bewildering diversity already enumerated for Madagascan Coffea, examination of field collections from the above-mentioned fieldwork and further field study in northern Madagascar revealed that it was necessary to describe six new species of Coffea: C. callmanderi A.P.Davis \& Rakotonas., C. darainensis A.P.Davis \& Rakotonas., C. kalobinonensis A.P.Davis \& Rakotonas., C. microdubardii A.P.Davis \& Rakotonas., C. pustulata A.P.Davis \& Rakotonas., and C. rupicola A. P.Davis \& Rakotonas. These new species are described here. Associated information, including distribution maps and provisional conservation assessments are also provided, and two species are illustrated with line drawings. These new species join others that have been recently described on the basis of the material collected from the mountainous regions of northern
Madagascar (e.g. Callmander et al. 2008, 2009, 2012, 2020; Randrianasolo \& Lowry 2009; Walhert 2016) and the Daraina area (Phillipson et al. 2018).

Three of the new species, Coffea darainensis, $C$. microdubardii and C. rupicola, are restricted to the protected area of Loky Manambato in the Daraina area, and a further two, C. callmanderi and C. kalobinonensis, are found only in the protected area of Galoko-Kalobinono. Coffea pustulata is also found in the Daraina area, but is not restricted to this locality, and occurs in other humid, evergreen forests of northern Madagascar. Loky Manambato represents a dozen forested massifs in central-northern Madagascar (Ranirison et al. 2018) and Galoko-Kalobinono two large massifs (Tahinarivony \& Callmander 2018) in the southern part of the narrow mountain Galoko chain running in a more or less north-south direction, c. $35 \mathrm{~km}$ long, close to the town of Ambanja (Moat \& Smith 2007). Until recently the forests of Loky Manambato and Galoko-Kalobinono were almost unknown botanically. The intense inventories of the last two decades have highlighted these two forest areas as places of high-level regional endemism (Callmander et al. 2008, 2009, 2012, 2020; Gautier et al. 2006; Nusbaumer et al. 2010; Phillipson et al. 2018; Randrianasolo \& Lowry 2009; Ranirison et al. 2018; Schatz \& Lowry 2020; Tahinarivony \& Callmander 2018; Wahlert 2016). These data and other information has led to Loky Manambato and Galoko-Kalobinono being encompassed in Madagascar's protected area network (Goodman et al. 2018). The description of the six new species of Coffea described here, further illustrate the value of targeted botanical exploration and the biological richness of these areas.

\footnotetext{
Accepted for publication 6 January 2021. Published online 13 August 2021

1 Royal Botanic Gardens, Kew, Richmond, Surrey, TW9 3AE, UK. e-mail: a.davis@kew.org.uk

2 Parc Botanique et Zoologique de Tsimbazaza, B.P. 4096, Tsimbazaza, 101, Antananarivo, Madagascar.

3 Kew Madagascar Conservation Centre (KMCC), Lot II J 131 B, Ambodivoanjo, Ivandry, 101, Antananarivo, Madagascar.
} 
The naming of the six new species described here brings the total number of Coffea species in Madagascar to 65 , and the number of coffee species to a global total of 130 .

\section{Material and Methods}

Herbarium material of Madagascan Coffea species was consulted in person, or from loans, held in the collections of the following institutes: G, K, MO, P, TAN (abbreviations after Holmgren et al. 1990; Thiers 2020). All specimens cited have been seen by the authors (type specimens indicated with an exclamation mark).

Dedicated fieldwork for Coffea was undertaken in Makira, near Maroantsetra (Province Toamasina; Region Analanjirofo; District Maroantsetra) and Kalobinono in the Galoka mountain range, near Ambanja (Province Antsiranana; Region Diana; District Ambanja) by the authors in 2007 and 2009, respectively. The measurements, colours and other details given in the descriptions are based mostly on herbarium specimens, but also from living plants and data derived from field notes. Further information on Coffea morphology is provided in Davis et al. (2005, 2006, 2007, 2011), Davis \& Rakotonasolo (2008), and Maurin et al. (2007).

Geo-referenced herbarium specimens were used as the data points for producing the distribution maps and conservation assessments, following error correction with the aid of Google Earth ${ }^{\circledR}$. The distribution map (Map 1) was produced using SimpleMappr (Shorthouse 2010). The conservation status of each Coffea species was provisionally assessed by applying the Red List Categories and Criteria (IUCN 2012, 2019), although formal conservation assessments were not submitted. The IUCN compliant software GeoCAT (Bachman et al. 2011), was used to generate the extent of occurrence (EOO) and/or area of occurrence (AOO) of a given cell width (Willis et al. 2003).

\section{Taxonomic Treatment}

1. Coffea pustulata A.P.Davis E Rakotonas., sp. nov. Type: Madagascar. Prov. Antsiranana; Region Sava; Distr. Vohemar: sous-préfecture de Vohemar, commune rurale de Daraina, Daraina, Forêt de Binara, 850 m, 7 Dec. 2005 (fl. bud), Ranirison $\mathcal{E}$ Nusbaumer PR 1012 (holotype G [G00090443]!; isotypes K!, P!, MO!, TEF!).

http://www.ipni.org/urn:lsid:ipni.org:names:77216866-1

Small tree, 3-6 m high, dbh (1.5-) $4-7 \mathrm{~cm}$. Bark not recorded. Branches $3.5-5 \mathrm{~mm}$ in diam., \pm smooth, sometimes slightly peeling, grey or light brown. Branchlets terete $2.5-5.3 \mathrm{~mm}$ in diam., \pm smooth, grey or light brown, glabrous. Stipules caducous, depressed angularovate to \pm deltate, $1.5-4.9 \times 2.4-3 \mathrm{~mm}$, subcoriaceous, glabrous; margin glabrous; apex obtuse to broadly acute. Leaves: petiole semi-articulated, $0.4-0.9 \mathrm{~cm}$ long, glabrous; lamina elliptic-obovate to obovate, $(4-)$ $5.4-8.4(-10.4) \times(1.5-) 2.8-4.2(-5.2) \mathrm{cm}$, subcoriaceous; base narrowly cuneate to attenuate; margin subrevolute to \pm flat; apex broadly acute or rarely obtuse, often subacuminate; abaxial surface: secondary veins prominent, $(5-) 6-8$ pairs, ascending at an angle of $30^{\circ}-45^{\circ}$, tertiary venation manifest or rather obscure, \pm reticulate; higher order venation obscure, ramified; texture smooth; domatia conspicuous, $2.5-6.4 \mathrm{~mm}$ from the midrib, against the secondary veins or not, orifice $0.1-0.4 \mathrm{~mm}$ in diam., or domatia becoming necrotic and then orifice $0.4-1.2$ (- 4.5) $\mathrm{mm}$ in diam., margin flat or slightly raised, glabrous; adaxial surface: venation very prominent (more so than the abaxial surface); domatia prominent, manifest as small, round or elliptic pustules, $0.8-2$ ($3.9) \times 0.7-1.5(-3.2 \mathrm{~mm})$, these often darker than leaf surface and sometimes necrotic. Inflorescences: 1 per leaf axil, each inflorescence 2 - 5-flowered, 7.5 - $10.4 \mathrm{~mm}$ long, very shortly branched or fasciculate, moderately to heavily covered with exudate; inflorescence axis (part bearing calyculi) $6.5-8.2 \mathrm{~mm}$ long. Calyculi 3, nested within each other, glabrous to sparsely puberulous (hairs c. $0.1 \mathrm{~mm}$ long), margins ciliate (hairs c. $0.2 \mathrm{~mm}$ long); basal (1st) calyculus $2.2-3.5 \times$ $3.7-4.3 \mathrm{~mm}$, stipular lobes semi-elliptic to broadly ovate, $0.4-0.6 \times 1.5-1.7 \mathrm{~mm}$, foliar lobes narrowly elliptic to narrowly obovate c. $1.5 \times 0.5 \mathrm{~mm}$; middle (2nd) calyculus $3.4-4 \times 6.2-6.7 \mathrm{~mm}$, stipular lobes broadly ovate to \pm deltate, $0.5-0.6 \times 2-2.3 \mathrm{~mm}$, foliar lobes not seen; upper (3rd) calyculus 5.3-6 $67.9-10.4$ $\mathrm{mm}$, stipular lobes broadly ovate, $2.4-3.1 \times 4.6-5.2$ $\mathrm{mm}$, foliar lobes not seen. Flowers poorly known (only very young buds and calyces seen), 5-merous; pedicel 0.4 - $0.6 \mathrm{~mm}$ long, glabrous, bractlets absent. Calyx (hypanthium) \pm obconical to campanulate, c. $1.5 \times 1.4$ $\mathrm{mm}$, smooth, glabrous; calyx limb shallowly 5-lobed, lobes, c. $0.1 \times 0.4 \mathrm{~mm}$, margin glabrous. Ovary: not seen. Corolla: only buds seen, smooth, other flower parts not seen. Fruit shortly oblong-ellipsoid to ellipsoid-obovoid, $10.4-10.9 \times 9.5-12.2 \mathrm{~mm}$ (when dried), slightly wrinkled (when dried), glabrous; fruit wall not seen; pedicel (2 -) $4-5.1 \mathrm{~mm}$ long, glabrous; calyx limb manifest, usually rather corky, disc flat or slightly protuberant. Seeds unknown. Figs 1, 2A, B.

RECOGNITION. Coffea pustulata is similar to C. sambavensis A.P.Davis \& Rakotonas. as both species have subcoriacous leaves and prominent extra axillary domatia (i.e. not positioned against the midrib but some distance from it [see below]), which appear as raised pustule-like protuberances on the upper leaf surface 


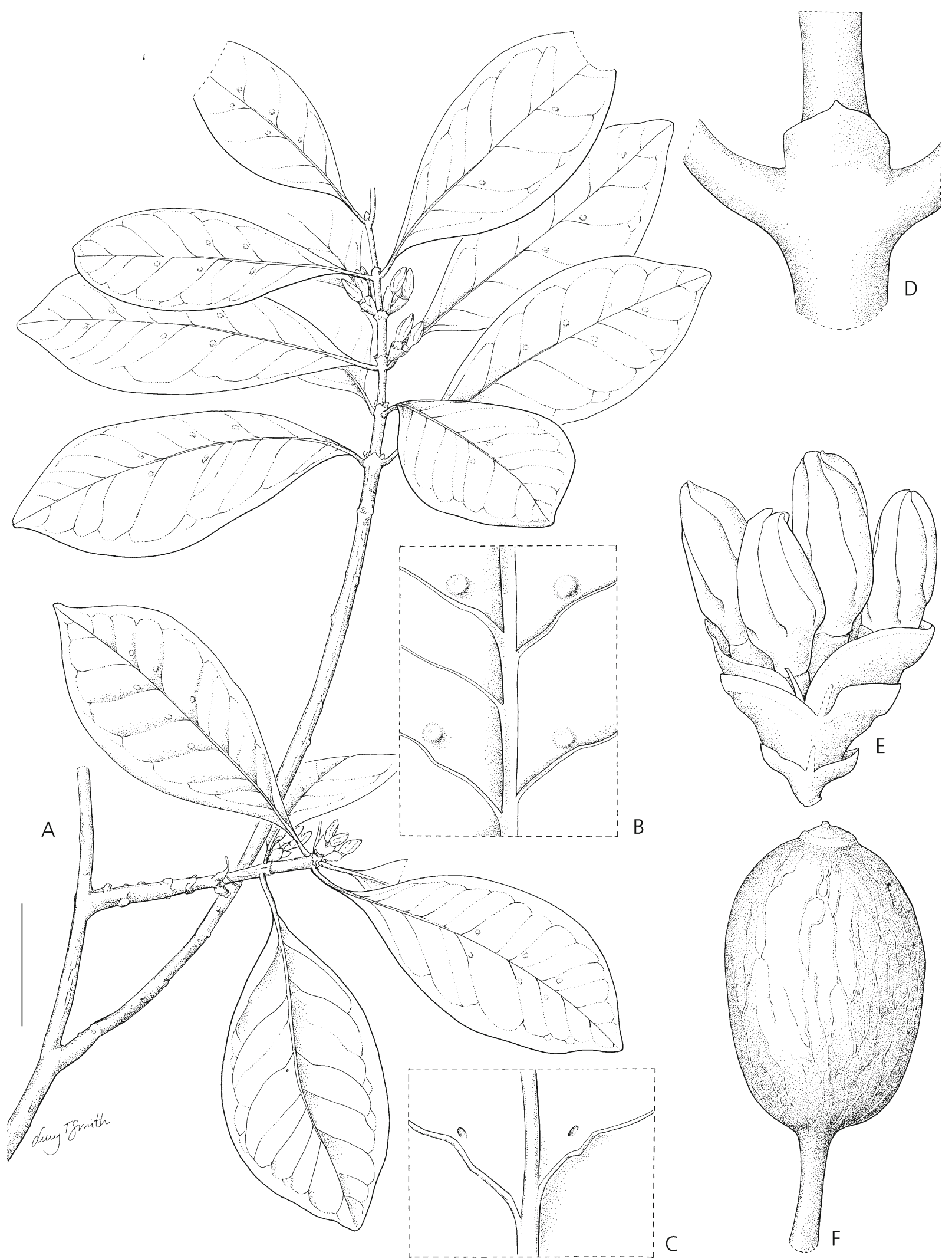

Fig. 1. Coffea pustulata. A habit; B leaf upper surface detail, showing domatia; $C$ leaf lower surface detail showing domatia; $D$ stipule; $E$ inflorescence with flower buds; $F$ fruit. Scale bar: $A=2.5 \mathrm{~cm} ; B=3.3 \mathrm{~cm} ; C, D, F=7 \mathrm{~mm} ; E=5 \mathrm{~mm}$. $[A-E$ from Ranirison \& Nusbaumer PR 1012; F from Gautier \& Ranirison LG 4681 (K)]. DRAWN BY LUCY T. SMITH. 

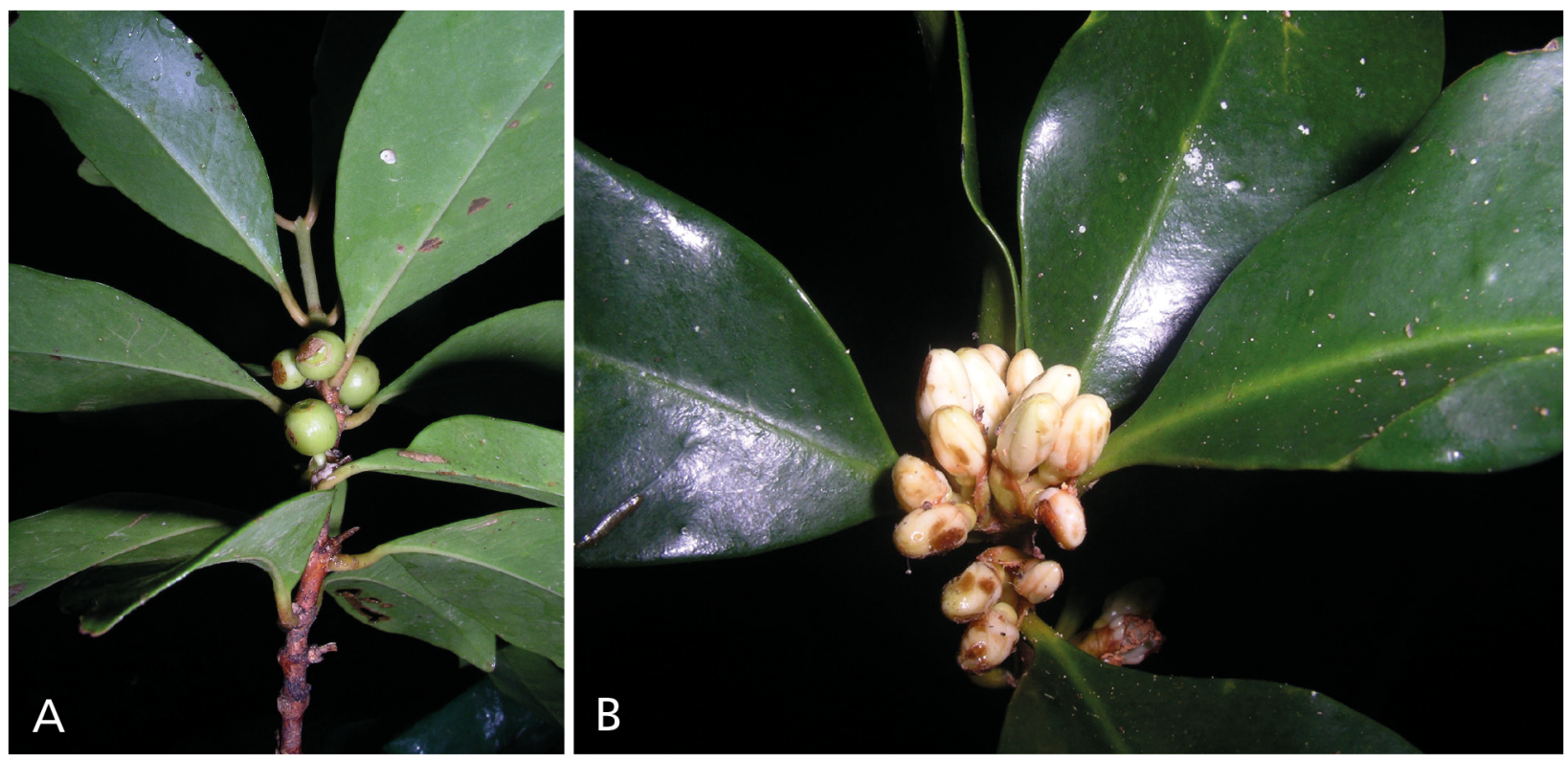

Fig. 2. Field images: A Coffea pustulata (immature fruit); B C. pustulata (with flower buds); $A=$ Nusbaumer LN 1025; B = Ranirison \& Nusbaumer PR 1012. PHOTOS: A L. NUSBAUMER; B P. RANIRISON.

(Figs 1A, B; 2B). Despite similarities, the two species are easily set apart morphologically. Coffea pustulata differs from C. sambavensis in the following (characters for C. sambavensis in square brackets): petioles semi-articulated, $0.4-0.9 \mathrm{~cm}$ long [vs petioles not articulated, $0.9-$ $2.6 \mathrm{~cm}$ long]; domatia $2.5-6.4 \mathrm{~mm}$ from the midrib, [vs $2.5-9(-13) \mathrm{mm}$ from the midrib]; basal $\left(1^{\text {st }}\right)$ calyculus $2.2-3.5 \mathrm{~mm}$ long [vs basal $\left(1^{\mathrm{st}}\right)$ calyculus $1.8-2.2 \mathrm{~mm}$ long]; flowering pedicel $0.4-0.6 \mathrm{~mm}$ long [vs pedicel 2$5.5 \mathrm{~mm}$ long]; fruit (when dried) shortly oblong-ellipsoid to ellipsoid-obovoid, $10.4-10.9 \times 9.5-12.2 \mathrm{~mm}$ [vs fruit shortly obovoid to \pm turbinate, $17-22 \times 14-18 \mathrm{~mm}$; and fruiting pedicel (2-) 4-5.1 mm long [vs pedicel (6 -) 9 - $14 \mathrm{~mm}$ long].

DISTRIBUTION. Endemic to northern Madagascar. See Map 1 and Specimens Examined.

SPECIMEnS EXAMINed. MAdAgASCAR. Prov. Antsiranana; Region Diana; Distr. Ambanja: Réserve Spéciale de Manongarivo, Andranomalaza, $200 \mathrm{~m}$ à l'W du point côté 1584, 1600 m, 18 March 1999 (fr.), L. G. Gautier et al. LG 3603 (G, K, P, MO, WAG, TEF). Prov. Antsiranana; Region Sava; Distr. Vohemar: sous-préfecture de Vohemar, commune rurale de Daraina, Daraina, Forêt de Binara, $810 \mathrm{~m}, 25$ March 2004 (fr.), L. G. Gautier E $\mathcal{~ P . ~ R a n i r i s o n ~ L G ~}$ 4681 (G, K, P, MO, TEF); sous-préfecture de Vohemar, commune rurale de Daraina, Daraina, forêt d'Antsahabe, 900 m, 22 Nov. 2004 (fr.), L. Gautier Eं L. Nusbaumer LG 4732 (G, K, P, TEF); sous-préfecture de Vohemar, commune rurale de Daraina, Daraina, Forêt d'Antsahabe, 900 m, 17 Jan. 2004 (young fr.), L. Nusbaumer LN 1025 (G, K, P, MO, TEF); Commune Daraina, Forêt
d'Analamazava (Binara), à $1 \mathrm{~h}$ de marche à l'ouest de village d'Ankijabe, 16 Nov. 2001 (fl. bud), R. Randrianaivo et al. 773 (MO). Prov. Antsiranana; Region Sava; Distr. Andapa. Reserve Naturelle Marojejy, along the trail to the summit of Marojejy Est, below the third camp, $1100-1300 \mathrm{~m}, 10$ Oct. 1988 (fl.), J. S. Miller et al. 3534 (K, MO, P, TAN). Prov. Toamasina; Region Analanjirofo; Distr. Maroantsetra. Makira Protected Area. Near Ankirindro, c. $9 \mathrm{~km} \mathrm{NW}$ of Ambinanitelo, $500 \mathrm{~m}$, 22 May 2007 (ster.), A. P. Davis E F. Rakotonasolo APD 4548 (K, TAN); Makira Protected Area, near Ankirindro, c. 9 km NW of Ambinanitelo, 600 m, 22 May 2007 (ster.), A. P. Davis E F F. Rakotonasolo APD 4552 (K, TAN); Andranobe, Fok. Ambanizana, Fir. Anjahana, Parc National de Masoala, 200 - 300 m, 17 April 1996 (fr.), J. Aridy et al. 243 (K, MO); hills E of village of Sahavary, up Andranofotsy R. from Maroantsetra, along trail toward headwaters of Sahafotra R. (Ravimbe swamp), Andilampananima hill, $350-450$ m, 23 Oct. 1986 (fl. bud), P. P. Lowry 4227 (MO, P).

HABITAT \& ECOLOGY. Humid evergreen forest, one record (Miller 3534) in lichen forest on exposed wind-swept ridges. On quartz and possibly other substrates; often recorded on rocks; recorded on humus rich soils. Elevation 200 - $1600 \mathrm{~m}$ above sea level.

CONSERVATION ASSESSMENT. Provisionally assessed as Vulnerable (IUCN 2012). VU B1ab(iii)+2ab(iii). B1 extent of occurrence (EOO) estimated to be less than $20,000 \mathrm{~km}^{2}$ (c. $19,968 \mathrm{~km}^{2}$ for Coffea pustulata); a severely fragmented or known to exist at no more than 


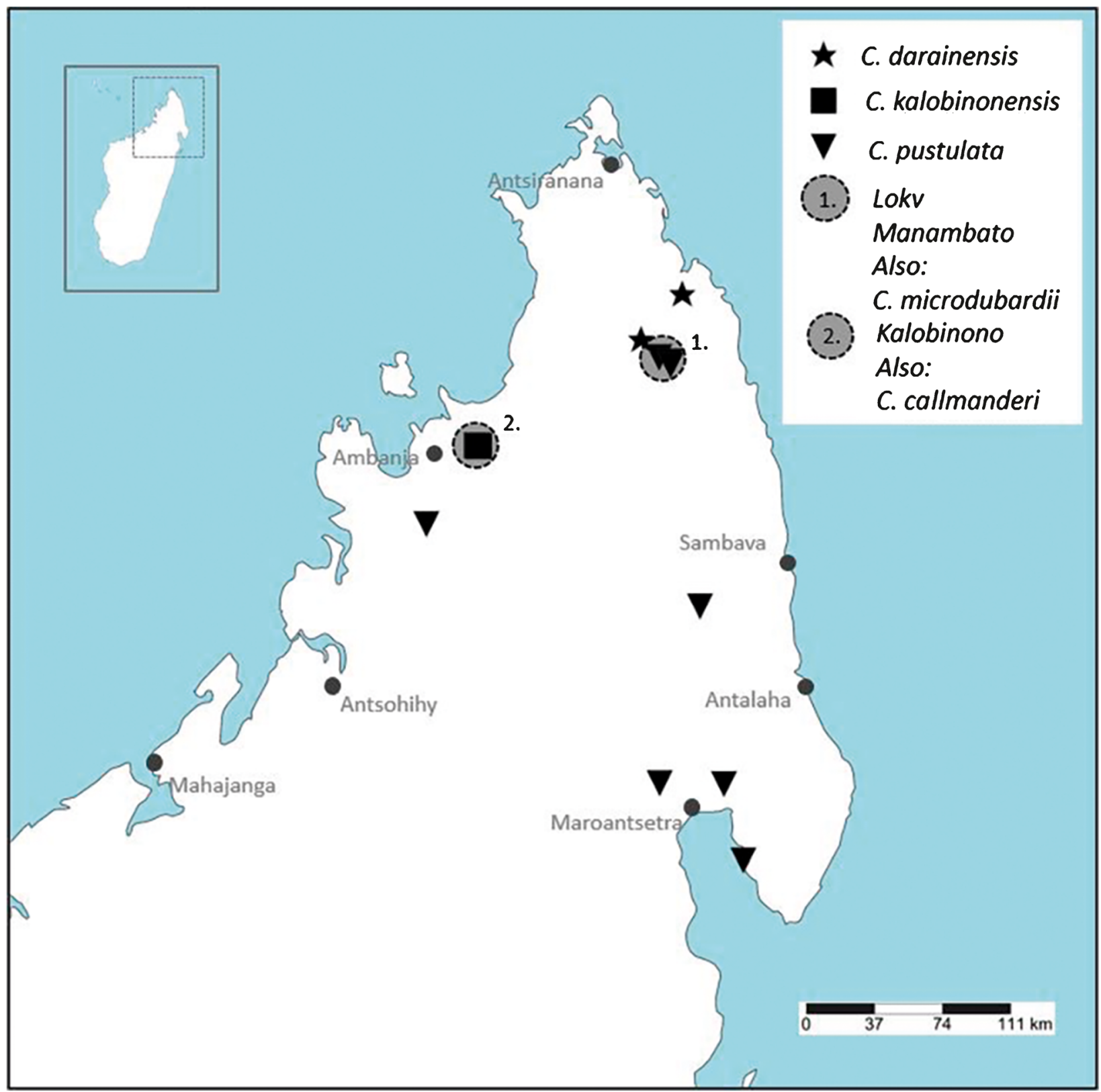

Map 1. Distribution of Coffea callmanderi, C. darainensis, C. kalobinonensis, C. microdubardii, C. pustulata and C. rupicola in northern Madagascar.

10 locations (seven locations for C. pustulata); and b (iii) — continuing decline projected, in area, extent and/or quality of habitat. B2 area of occupancy (AOO) estimated to be less than $2000 \mathrm{~km}^{2}\left(36 \mathrm{~km}^{2}\right.$ for C. pustulata, at a cell width of $2 \mathrm{~km}$ ); a - severely fragmented or known to exist at no more than 10 locations (see above); and $\mathrm{b}$ and $\mathrm{b}$ (iii) - continuing decline projected, in area, extent and/or quality of habitat. The AOO is well within the limits for the Vulnerable category, and falls with the Endangered category limits, but we project that there could be further populations in northern Madagascar as yet unknown. We do not predict that the EOO will increase significantly, after further fieldwork. The distribution of C. pustulata includes populations in five protected areas, including: Loky Manambato, Makira Natural Park, Manongarivo Special Reserve, Marojejy National Park, and Masoala National Park.

PHENOLOGY. Imperfectly known — probably flowering from November to December; fruiting from January to April.

ETYMOLOGY. Coffea pustulata is so named due to the pustular appearance of the upper leaf surface (Figs 1A; $2 \mathrm{~B}$ ), which is caused by the large swollen domatia located on the lower leaf surface (Fig. 1B).

VERNACULAR NAME. Ompangavo (Aridy 243). 
NOTES. Coffea pustulata shares much in common with C. sambavensis A.P.Davis \& Rakotonas. (Davis \& Rakotanasolo 2001b), but there are obvious differences between these two species (see Recognition), and especially the much larger fruits in the latter species. Both species occur in northern Madagascar, but their distribution and ecology are different. Coffea pustulata occurs in the districts of Vohimarina, Ambanja, and Andapa (Prov. Antsiranana) and in Maroantsetra (Prov. Toamasina), at 200 - $1600 \mathrm{~m}$ above sea level, whereas C. sambavensis in restricted to the districts of Vohimarina and Sambava (Prov. Antsiranana), at $0-250 \mathrm{~m}$ above sea level, and is predominately confined to littoral forests. See Map 1.

2. Coffea microdubardii A.P.Davis $\mathcal{E}$ Rakotonas., sp. nov. Type: Madagascar. Prov. Antsiranana; Region Sava; Distr. Vohimarina: sous-préfecture de Vohemar, commune rurale de Daraina, Forêt de Binara, $340 \mathrm{~m}$, 20 Dec. 2003 (fl.), Nusbaumer LN 843 (holotype G [G00006870]!; isotypes K!, P!, MO!, TEF!).

http:/ /www.ipni.org/urn:lsid:ipni.org:names:77216865-1

Treelet $2.5-2.8 \mathrm{~m}$ high, diam. at base c. $2.5 \mathrm{~cm}$. Bark not recorded. Branches $2.9-4 \mathrm{~mm}$ in diam., \pm smooth or slightly peeling, light brown to grey-brown. Branchlets \pm terete, $1.6-2.2 \mathrm{~mm}$ in diam., \pm the same colour and texture as the branches, upper portions often dark brown, glabrous in lower part, uppermost minutely puberulous to minutely pubescent (hairs < $0.1 \mathrm{~mm}$ long). Stipules caducous, deltate to depressed ovate, $0.9-1.6 \times 0.9-1.3 \mathrm{~mm}$, subcoriaceous, minutely puberulous (hairs $<0.1 \mathrm{~mm}$ long); margin ciliate (hairs c. $0.1 \mathrm{~mm}$ long); apex obtuse to broadly obtuse. Leaves: petiole $0.2-0.5 \mathrm{~cm}$ long, puberulous like the branchlets; lamina oval to oval-ovate, or obovate, or \pm elliptic, $(2.2-) 3-5.2 \times(1-) 1.3-3.3$ $\mathrm{cm}$, subcoriaceous; base cuneate; margins subrevolute to flat; apex shortly caudate to caudate, cauda $0.2-0.7$ (- 1) cm long; abaxial surface: secondary veins manifest to prominent, $(5-) 6-8$ pairs, ascending at an angle of c. $45^{\circ}$, tertiary venation manifest to prominent, often difficult to distinguish from the secondary venation, reticulate but mostly distinctly parallel to the secondary veins (Garcinia-like), higher order venation obscure, \pm ramified; texture smooth; domatia manifest to prominent, located in the axils of the secondary veins, against the midrib, orifice oval 0.7 - $1.2 \times 0.2-0.4 \mathrm{~mm}$, margin slightly raised or flat, sparsely to densely puberulous; adaxial surface: venation obscure; domatia invisible. Inflorescences interfoliar, restricted to the uppermost axils (1st or 2nd pair of leaves), 1 per leaf axil, 3 - 6-flowered, 7 $10 \mathrm{~mm}$ long, with more than one order of branching, lightly covered with exudate; inflorescence axis (bear- ing calyculi) 2.7 - $5.8 \mathrm{~mm}$ long. Calyculi 3, shortly stalked to stalked (stalks 1.2 - $2.2 \mathrm{~mm}$ long); sparsely and minutely puberulous (hairs $<0.1 \mathrm{~mm}$ long) or sometimes \pm glabrous, margins ciliate (hairs 0.1 $0.2 \mathrm{~mm}$ long) and with colleters (narrowly conical to narrowly ellipsoid, $0.2-0.3 \mathrm{~mm}$ long), particularly on the upper calyculus; basal (1st) calyculus $1.2-1.5 \times 1.2$ - 1.4, stipular lobes shallowly triangular to deltate, or ovate, $0.4-0.9 \times 0.6-0.8 \mathrm{~mm}$, foliar lobes \pm deltate $\mathrm{c}$. $0.2 \times 0.2 \mathrm{~mm}$; middle (2nd) calyculus $1-1.2 \times 1.2-1.4$, stipular lobes broadly ovate to deltate, $1-1.1 \times 0.7-1.2$ $\mathrm{mm}$, foliar lobes \pm ovate to elliptic, c. $0.5 \times 0.3 \mathrm{~mm}$; upper (3rd) calyculus $0.9-1.2 \times 1.2-1.5$, stipular lobes \pm ovate, c. $1 \times 0.8 \mathrm{~mm}$, foliar lobes ovate to elliptic $0.3-0.6 \times 0.3$ $\mathrm{mm}$, or upper calyculus bract-like, comprising of (1-) 2 opposite stipular lobes, broadly ovate to ovate, or ovatetriangular, $0.4-0.7 \times 0.5-0.6 \mathrm{~mm}$. Flowers 5-merous; pedicel $2.5-3.7 \mathrm{~mm}$ long, puberulous (hairs $<0.1 \mathrm{~mm}$ long), bractlets $1-3$, alternate, \pm truncate to broadly ovate, c. $0.2 \mathrm{~mm}$ long, margins entire, each bractlet bearing 3-6 colleters (narrowly ellipsoid to cylindrical, $0.2-0.3 \mathrm{~mm}$ long). Calyx (hypanthium) \pm ellipsoid (but constricted below the calyx limb) to \pm urceolate, $1.5-1.7$ $\times 1 \mathrm{~mm}$, texture \pm smooth, puberulous (hairs $<0.1 \mathrm{~mm}$ long); calyx limb undulate to c. 7-lobed, margin ciliate (hairs <0.1 mm long), beset with $12-14$ colleters. Ovary: disc prominent, \pm hemispherical to shortly tubular, entire. Corolla funnel-shaped, $9-13 \times 9-16.8 \mathrm{~mm}$, smooth; corolla tube \pm the same length as the corolla lobes, $6-7 \mathrm{~mm}$ long; corolla lobes $7-8 \times 2.3-2.5 \mathrm{~mm}$. Stamens: filaments c. $1 \mathrm{~mm}$ long; anthers $3.4-3.5 \mathrm{~mm}$ long. Style 10.5 - $11 \mathrm{~mm}$ long; stigma lobes $1.5-1.6 \mathrm{~mm}$ long. Fruit 1- or 2-seeded ellipsoid to broadly ellipsoid, sometimes slightly asymmetric (calyx limb and pedicel off-centre), $7.2-7.4 \times 9-9.3 \mathrm{~mm}$, smooth (when dried), colour unknown, glabrous or very sparsely puberulous (hairs < $0.1 \mathrm{~mm}$ long); fruit wall thickness unknown; pedicel 2.5 - $3.7 \mathrm{~mm}$ long, sparsely puberulous (hairs < $0.1 \mathrm{~mm}$ long); calyx limb prominent, disc rather prominent. Seeds unknown. Figs 3, 4B, C.

RECOGNITION. Coffea microdubardii resembles C. dubardii Jum., due to the presence of numerous prominent tertiary veins that run parallel to the secondary veins, and the general morphology of the inflorescence and the flowers. Overall, microdubardii represents a much smaller version of $C$. dubardii, but with many differences in the number of features and also nonquantitative differences. The main differences between these species are as follows (dimensions and character states for $C$. dubardii given in square brackets): treelet $2.5-2.8 \mathrm{~m}$ high [vs treelet or small tree, $(1-) 1.7-6(-7) \mathrm{m}$ high]; petiole $0.2-0.5 \mathrm{~cm}$ long, puberulous [vs $(0.5-) 0.8-1.1 \mathrm{~cm}$ long, glabrous]; leaf blade $(2.2-) 3-5.2 \times(1-) 1.3-$ $3.3 \mathrm{~cm}$ [vs (5-) $7-10.5(-12.5) \times(2.2-) 3-5.5(-$ $6.5) \mathrm{cm}$ ]; secondary veins $(5-) 6-8$ pairs [vs $(6-) 8-$ 


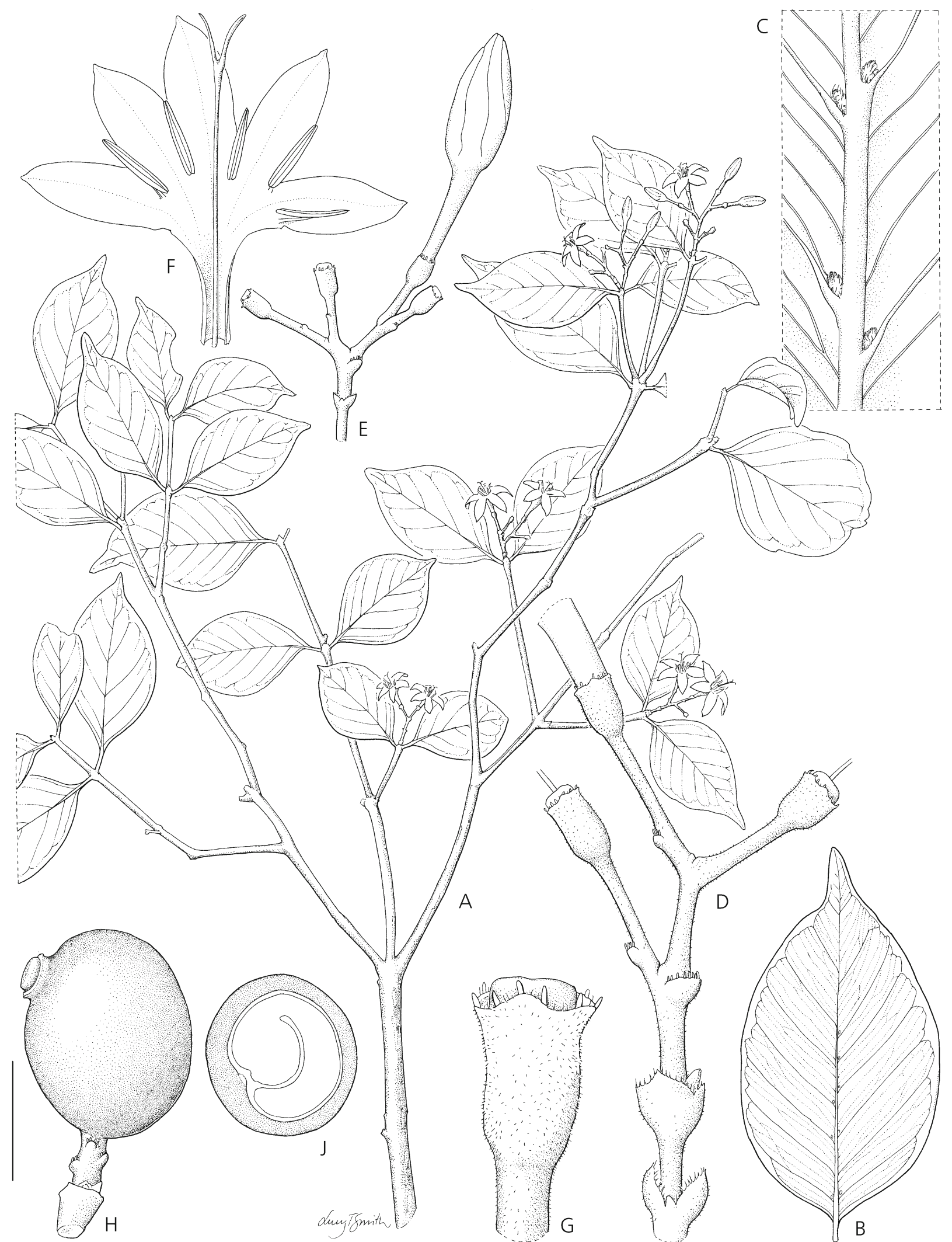

Fig. 3. Coffea microdubardii. A habit; B leaf (lower surface with detail of venation); C leaf (lower surface showing domatia); D inflorescence; $E$ inflorescence section with flower bud; $F$ corolla (cut open); $G$ hypanthium (including calyx); $H$ fruit; J fruit in transverse section. Scale bar: $A=2.5 \mathrm{~cm} ; B=1.5 \mathrm{~cm} ; C=2 \mathrm{~mm} ; D=3 \mathrm{~mm} ; E=7 \mathrm{~mm} ; F, H, J=5 \mathrm{~mm} ; G=1 \mathrm{~mm}$. $[A-$ G from Nusbaumer LN 843 (K); H, J from Ranirison PR 797 (K)]. DRAWN BY LUCY T. SMITH. 

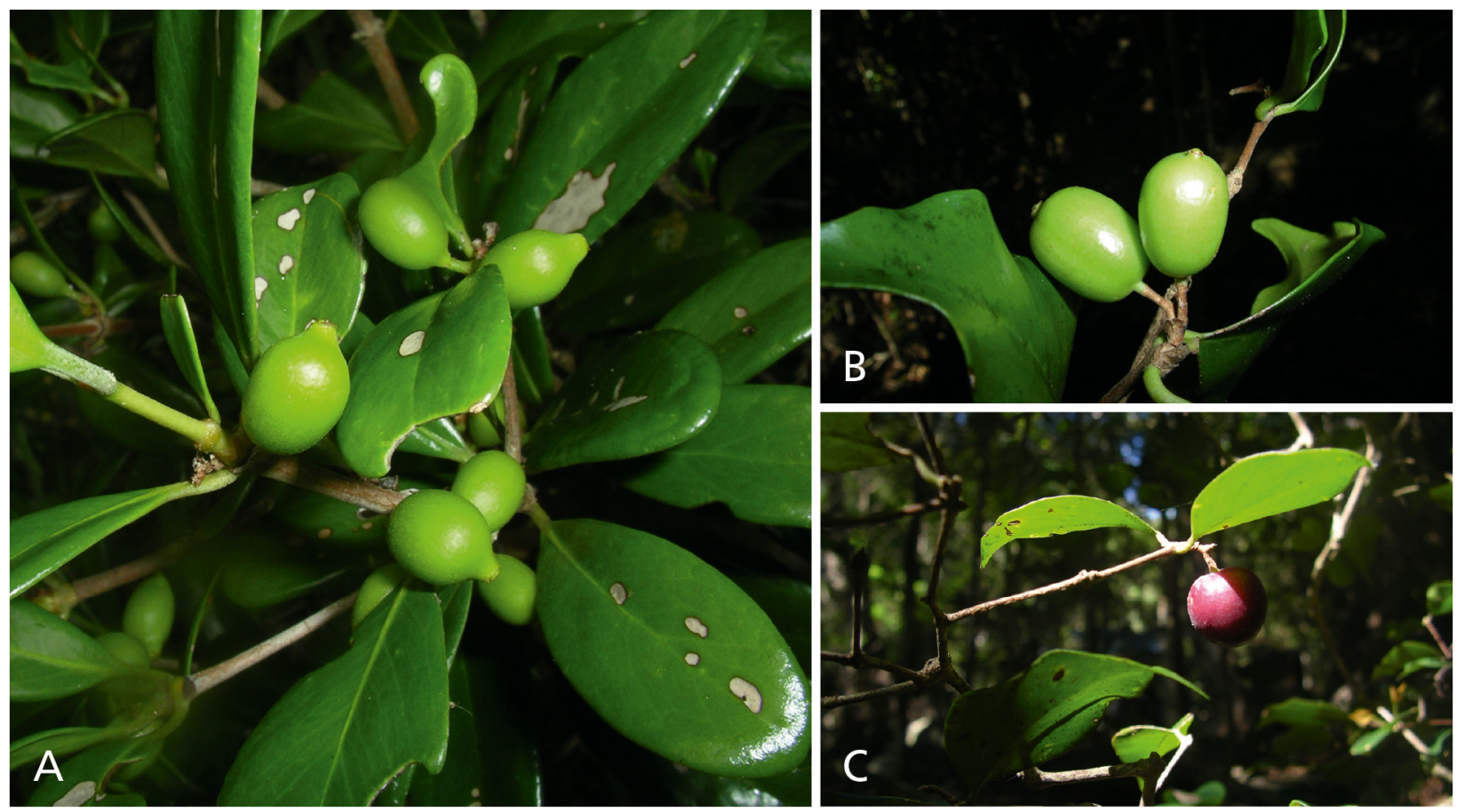

Fig. 4. Field images: A Coffea darainensis (immature fruit); B C. microdubardii (immature fruit); C C. microdubardii (mature fruit). A = Ranirison PR 689; $\mathrm{B}=$ Ranirison PR 797; C = Nusbaumer LN 843. PHOTOS: A, B P. RANIRISON; C L. NUSBAUMER.

12 (- 14) pairs]; leaf domatia sparsely to densely puberulous (hairs $0.1-0.2 \mathrm{~mm}$ long) [vs distinctly pubescent (hairs many, $0.2-0.4 \mathrm{~mm}$ long)]; inflorescences restricted to the upper nodes of the shoot, 1 per leaf axil, each inflorescence 3 - 6-flowered, 7 $10 \mathrm{~mm}$ long [vs inflorescences in several nodes of the shoot, 1 or $2(-3)$ per leaf axil, each inflorescence (3 -) 4 - 8 (-10)-flowered, 5 - 12 (-15) mm long]; calyx (incl. hypanthium) $1.5-1.7 \times 1 \mathrm{~mm}$ [vs $1.8-2.5 \times 1.8$ $-2.3 \mathrm{~mm}$ ]; corolla $9-13 \times 9-16.8 \mathrm{~mm}$ [vs (10 -) $14-$ $19 \times 10-17.1 \mathrm{~mm}]$; corolla tube \pm the same length as the corolla lobes, $6-7 \mathrm{~mm}$ long [vs corolla tube distinctly longer than corolla lobes, (6-) $8-12 \mathrm{~mm}$ long]; stamens: filaments c. $1 \mathrm{~mm}$ long [vs $2-2.2 \mathrm{~mm}$ long]; anthers $3.4-3.5 \mathrm{~mm}$ long [vs 5.5 - $7 \mathrm{~mm}$ long]; style $10.5-11 \mathrm{~mm}$ long [vs $13-15 \mathrm{~mm}$ long]; fruit 7.2 $-7.4 \times 9-9.3 \mathrm{~mm}$ [vs $8-11 \times 6-10 \mathrm{~mm}$ ].

DISTRIBUTION. Endemic to northern Madagascar and restricted to the Loky Manambato Protected Area (Prov. Antsiranana; Region Sava; District Vohemar). See Map 1 and Specimens Examined.

SPECIMENS EXAMINED. MADAGASCAR. Prov. Antsiranana; Region Sava; Distr. Vohimarina: sous-préfecture de Vohemar, commune rurale de Daraina, Daraina, Forêt d'Antsahabe, $580 \mathrm{~m}, 3$ May 2004 (fr.), P. Ranirison PR 797 (G, K, P, MO, TEF); Daraina, Ankarafa, Antsahabe, $5 \mathrm{~km}$ à l'Ouest du village de Daraina, 595 m, 30 Oct. 2005 (fr.), J. Be et al. 162
(MO); sous-préfecture de Vohemar, commune rurale de Daraina, Daraina, Forêt d'Ankaramy, 330 m, 21 Dec. 2005 (fr.), P. Ranirison Eं L. Nusbaumer PR 1036 (G).

HABITAT \& ECOLOGY. Transitional (humid, evergreendeciduous) to seasonally dry (semi-deciduous) forest. On rocks, boulders, and other rocky substrates. Elevation 340 - $580 \mathrm{~m}$ above sea level.

CONSERVATION ASSESSMENT. Provisionally assessed as Endangered (IUCN 2012). EN Blab(iii)+2ab(iii). B1 - extent of occurrence (EOO) estimated to be less than $5000 \mathrm{~km}^{2}$ (c. $21 \mathrm{~km}^{2}$ for C. microdubardii); a severely fragmented known to exist at three locations; and $\mathrm{b}$ (iii) - continuing decline projected, in area, extent and/or quality of habitat. B2 area of occupancy (AOO) estimated to be less than $500 \mathrm{~km}^{2}\left(16 \mathrm{~km}^{2}\right.$ for C. microdubardii, at a cell width of $2 \mathrm{~km} ; 4 \mathrm{~km}^{2}$ at a cell width of $1 \mathrm{~km}$ ); a - severely fragmented (see above); and $\mathrm{b}$ and $\mathrm{b}$ (iii) - continuing decline projected, in area, extent and/or quality of habitat. The EOO and AOO both fall well within the limits for the EN category and almost within the Critically Endangered (CR) category. Further fieldwork is required to provide more precise distribution metrics and threat information for this species. The distribution of C. microdubardii includes populations in the Loky Manambato Protected Area in the forests of Binara, Antsahabe and Ankaramy. 
PHENOLOGY. Imperfectly known - flowering from December, and probably November; fruiting from late October to May.

ETYMOLOGY. Coffea microdubardii is so named due to resembling a much smaller version of $C$. dubardii.

NOTES. Coffea microdubardii looks like a much smaller version of $C$. dubardii, a quite frequently encountered Coffea species of northern Madagascar. These two species are easy to separate morphologically. The size of the leaves and number of secondary veins offers an easy means of recognition: leaves $3-5.2 \mathrm{~cm}$ long and with $6-8$ pairs of secondary veins in C. microdubardii, versus mostly $7-10.5 \mathrm{~cm}$ long and with $8-12$ pairs of secondary veins in $C$. dubardii. In addition, C. microdubardii does not have the drought resilience adaptations that are present in $C$. dubardii, including 'resting' shoot-buds and partial deciduousness, i.e. leaves relaxing due to movement in the petiole, or sometimes falling from the plant, during times of heat/drought stress.

Coffea microdubardii and C. dubardii occur in northern Madagascar, but their distributions do not overlap: the former is restricted to the Daraina area, whereas the latter is rather widespread in northern and northeastern Madagascar but is absent from Daraiana (see Map. 1).

3. Coffea rupicola A.P.Davis $\mathcal{E}^{\Im}$ Rakotonas., sp. nov. Type: Madagascar: Prov. Antsiranana; Region Sava; Distr. Vohimarina: sous-préfecture de Vohemar, commune rurale de Daraina, Daraina, forêt d'Antsahabe, 850 m, 13 Dec. 2004 (fl.), Nusbaumer Ẽ Ranirison LN 1345 (holotype G [G00019393]!; isotypes K!, P!, MO!, TEF!).

http://www.ipni.org/urn:lsid:ipni.org:names:77216867-1

Treelet $1.5-3 \mathrm{~m}$ high, dbh or diam. at base unknown. Bark texture unknown, reddish brown. Branches 1.9 $3 \mathrm{~mm}$ in diam., \pm smooth or slightly peeling, brown to reddish brown. Branchlets \pm terete, $1-1.6 \mathrm{~mm}$ in diam., \pm the same colour and texture as the branches, glabrous. Stipules caducous, depressed ovate, $0.6-0.9$ $\times 0.4-0.6 \mathrm{~mm}$, subcoriaceous, glabrous; margin glabrous; apex broadly obtuse. Leaves: petiole 0.1 $0.45 \mathrm{~cm}$ long, glabrous; lamina narrowly to broadly elliptic $(2.7-) 3.9-6 \times(1.2-) 1.5-3.6 \mathrm{~cm}$, subcoriaceous; base cuneate; margins subrevolute to flat; apex acute to obtuse, or shortly caudate c. $0.2 \mathrm{~cm}$ long; abaxial surface: secondary veins manifest to prominent, $5-7$ pairs, ascending at an angle of $\mathrm{c}$. $45^{\circ}$, tertiary venation manifest to prominent, often difficult to distinguish from the secondary venation, reticulate but mostly distinctly parallel to the secondary veins (Garcinia-like), higher order venation obscure, \pm ramified; texture smooth; domatia obscure or sometimes lacking, located in the axils of the secondary veins, against the midrib, orifice $0.1-0.3 \mathrm{~mm}$ in diam., oval to slit-like, margin slightly raised and swollen, glabrous; adaxial surface: venation manifest to rather prominent; domatia invisible to obscure. Inflorescences interfoliar, restricted to the uppermost axils (1st or 2nd pair of leaves), 1 per leaf axil, each inflorescence 1 - 3-flowered, $4-7 \mathrm{~mm}$ long, with 1 order of branching, lightly covered with exudate, or hardly at all; inflorescence axis (bearing calyculi) 0.9 $2.2 \mathrm{~mm}$ long. Calyculi 3, nested within each other; puberulous to densely puberulous (hairs $<0.1 \mathrm{~mm}$ long), margins glabrous; basal (1st) calyculus $0.8-1.2$ $\times 0.9-1 \mathrm{~mm}$, stipular lobes shallowly triangular to deltate, $0.4-0.6 \times 0.8 \mathrm{~mm}$, foliar lobes elliptic-ligulate, c. $0.2 \times 0.1 \mathrm{~mm}$; middle (2nd) calyculus $0.9-1.6 \times 1-$ $1.2 \mathrm{~mm}$, stipular lobes broadly ovate to deltate, 0.5 $0.6 \times 0.8-0.9 \mathrm{~mm}$, foliar lobes \pm elliptic-ligulate, $0.2-$ $0.3 \times 0.1 \mathrm{~mm}$; upper (3rd) calyculus $2-2.5 \times 1.6-2.1$ $\mathrm{mm}$, stipular lobes broadly ovate to deltate, $0.8-1.6 \times$ $1.4-1.6 \mathrm{~mm}$, foliar lobes \pm elliptic-ligulate, $0.2-0.3 \times$ $0.1-0.2 \mathrm{~mm}$. Flowers 5-merous; pedicel $0.7-1.6 \mathrm{~mm}$ long, glabrous, bractlets absent. Calyx (hypanthium) obconical to \pm turbinate, $1.5-1.7 \times 1.2 \mathrm{~mm}$, texture \pm smooth, glabrous; calyx limb shallowly 5 -lobed, margin sparsely ciliate (hairs $<0.1 \mathrm{~mm}$ long), beset with c. 5 colleters. Ovary: disc low domed, entire. Corolla funnelshaped, $10-10.2 \times 10-10.4 \mathrm{~mm}$, smooth; corolla tube slightly longer than the corolla lobes, 6.2 $6.4 \mathrm{~mm}$ long; corolla lobes $4.8-5 \times 2.4-2.5 \mathrm{~mm}$. Stamens: filaments $2-2.2 \mathrm{~mm}$ long; anthers $3.4-$ $3.6 \mathrm{~mm}$ long. Style $10-10.3 \mathrm{~mm}$ long; stigma lobes 3.5 - $3.6 \mathrm{~mm}$ long. Fruit (immature) narrowly ellipsoid. 7.5 $\times 4 \mathrm{~mm}$, smooth (when dried), colour unknown, glabrous; fruit wall thickness unknown; pedicel c. $2.5 \mathrm{~mm}$ long, glabrous; calyx limb and disc manifest to inconspicuous. Seeds unknown.

RECOGNITION. Coffea rupicola closely resembles C. microdubardii in size and overall appearance, and both species occur in close proximity in certain locations in the Daraina area. The leaf morphology is very similar in overall appearance, but closer inspection reveals numerous differences between these two species (dimensions and character states for C. microdubardii are given in square brackets): domatia obscure or sometimes lacking, apertures slit-like or oval, glabrous [vs prominent, aperture oval, sparsely to densely puberulous; Fig. 3C], inflorescences 1 - 3flowered, $4-7 \mathrm{~mm}$ long, with 1 order of branching [vs 3 -6-flowered, $7-10 \mathrm{~mm}$ long, with more than one order of branching, Fig. 3D]; inflorescence axis (bearing calyculi) 0.9 - $2.2 \mathrm{~mm}$ long [vs 2.7 $5.8 \mathrm{~mm}$ long]; flower pedicel 0.7 - $1.6 \mathrm{~mm}$ long, glabrous [vs $2.5-3.7 \mathrm{~mm}$ long, and puberulous], and lacking bractlets [vs bractlets present, Fig. 3D]; calyx 
(hypanthium) glabrous (vs puberulous, Fig. 3G]; calyx limb shallowly 5-lobed, [vs undulate to c. 7-lobed, Fig. $3 \mathrm{G}$ ] and beset with c. 5 colleters [vs $12-14$ colleters]; corolla lobes $4.8-5 \times 2.4-2.5 \mathrm{~mm}$ [vs $7-8 \times 2.3-2.5$ $\mathrm{mm}]$.

DISTRIBUTION. Endemic to northern Madagascar (Prov. Antsiranana; Region Sava; Distr. Vohemar) and restricted to the Forest of Antsahabe in the Loky Manambato Protected Area. See Map 1 and Specimens Examined.

SPECIMENS EXAMINED. MAdAgasCAR. Prov. Antsiranana; Region Sava; Distr. Vohimarina: sous-préfecture de Vohemar, commune rurale de Daraina, Daraina, Forêt d'Antsahabe, 940 m, 14 Dec. 2004 (y. fr), L. Nusbaumer $\mathcal{E}$ P. Ranirison LN 2153 (G).

HABITAT \& ECOLOGY. Seasonally dry (semi-deciduous) or evergreen (humid)-seasonally dry transitional forest; on plate (pavement-like) rocks. Elevation 850 $940 \mathrm{~m}$ above sea level.

CONSERVATION ASSESSMENT. Provisionally assessed as Critically Endangered (IUCN 2012). CR Blab(iii)+2ab (iii). B1 - extent of occurrence (EOO) estimated to be less than $100 \mathrm{~km}^{2}$ (c. $0.0 \mathrm{~km}^{2}$ for Coffea rupicola as there are only two points); a - severely fragmented and known to exist at a single location; and b (iii) continuing decline projected, in area, extent and/or quality of habitat. B2 area of occupancy (AOO) estimated to be less than $10 \mathrm{~km}^{2}\left(4 \mathrm{~km}^{2}\right.$ for C. rupicola, at a cell width of $2 \mathrm{~km} ; 1 \mathrm{~km}^{2}$ at a cell width of $\left.1 \mathrm{~km}\right)$; a - severely fragmented (see above); and b and b (iii) - continuing decline projected, in area, extent and/or quality of habitat. The EOO and AOO both fall well within the limits for the CR category; even if other subpopulations are found throughout (and at the margins) of the single location, the EOO would still fall well within this category $\left(42.3 \mathrm{~km}^{2}\right)$, and the AOO is highly unlikely to exceed 10 $\mathrm{km}^{2}$. A cell width of $1 \mathrm{~km}$ is probably most appropriate for this species because the subpopulations of this species are sparsely populated and easily less than 1 $\mathrm{km}^{2}$. The distribution of C. rupicola includes populations in the Loky Manambato Protected Area, in the forest Antshabe.

PHENOLOGY. Imperfectly known - flowering in December; fruiting from December onwards.

ETYMOLOGY. Coffea rupicola is so named due to its association with rocky environments.

NOTES. Coffea rupicola looks very similar to C. microdubardii, which also occurs in the Forest of Antsahabe in the Loky Manambato Protected Area, on rocky substrates. There are, however, numerous differences between these species, as outlined in Recognition (see above).

4. Coffea darainensis A.P.Davis $\mathcal{E}$ Rakotonas,, sp. nov. Type: Madagascar. Prov. Antsiranana; Region Sava; Distr. Vohimarina: sous-préfecture de
Vohemar, commune rurale de Daraina, Daraina, Forêt d'Ambohitsitondroina, 250 m, 5 Jan. 2006 (fl. \& fr.), Ranirison E Nusbaumer PR 1045 (holotype G [G00090473]!; isotypes $\mathrm{K}$ !, MO!, P!, TEF!).

http://www.ipni.org/urn:lsid:ipni.org:names:77216863-1

Small tree, $2.5-3 \mathrm{~m}$ high, dbh c. $3 \mathrm{~cm}$. Bark not recorded. Branches c. $5 \mathrm{~mm}$ in diam., lightly fissured, light brown and grey. Branchlets \pm terete, $1.5-$ $3.4 \mathrm{~mm}$ in diam., \pm the same colour and texture as the branches, the young parts minutely puberulous (hairs $<0.1 \mathrm{~mm}$ long). Stipules caducous, \pm triangular, $0.7-1.5 \times 1.7-2.2 \mathrm{~mm}$, subcoriaceous, puberulous like the shoots; margin minutely ciliate (hairs < $0.1 \mathrm{~mm}$ long), or glabrous; apex acute to broadly acute. Leaves: petiole $0.5-0.7 \mathrm{~cm}$ long, glabrous; lamina obovate to broadly obovate, or obovate-elliptic, $3.5-5.6 \times(1-) 1.2-3 \mathrm{~cm}$, coriaceous; base acute to attenuate; margins flat to revolute; apex rounded to obtuse; abaxial surface: secondary veins prominent, 4 - 6 pairs, ascending at an angle of c. $45^{\circ}$, tertiary venation manifest to obscure, \pm reticulate; higher order venation obscure to invisible, reticulate; texture smooth; domatia inconspicuous, located in the axils of the secondary veins, against the midrib, orifice $0.2-$ $0.4 \mathrm{~mm}$ in diam., margin slightly swollen or flat, sparsely puberulous (hairs c. 0.1) mm long); adaxial surface: venation \pm invisible to manifest; domatia invisible to obscure. Inflorescences interfoliar: 1 or 2 per leaf axil, each inflorescence 3 - 5-flowered, (3.2 -) $5-6.9 \mathrm{~mm}$ long, branched, moderately covered with exudate; inflorescence axis (part bearing calyculi) 2.9 - $5 \mathrm{~mm}$ long. Calyculi 3, nested within each other, minutely puberulous (hairs c. $0.1 \mathrm{~mm}$ long), margins minutely ciliate (hairs c. $0.1 \mathrm{~mm}$ long); basal (1st) calyculus $1.4-2 \times 1.8-2.2 \mathrm{~mm}$, stipular lobes shallowly triangular to deltate, $0.3 \times 0.3-0.5 \mathrm{~mm}$, foliar lobes broadly ovate to ovate, $0.3-0.4 \times 0.6-0.7$ $\mathrm{mm}$; middle (2nd) calyculus $1.2-2 \times 1.9-2.4 \mathrm{~mm}$, stipular lobes shallowly deltate shallowly triangular, 0.4 $-0.7 \times 0.3-0.7 \mathrm{~mm}$, foliar lobes \pm deltate to elliptic, $0.4-0.7 \times 0.3-0.4 \mathrm{~mm}$; upper (3rd) calyculus $1.4-$ $1.9 \times 1.7-2.1 \mathrm{~mm}$, stipular lobes deltate to shallowly triangular, $0.5-0.7 \times 0.5-0.7 \mathrm{~mm}$, foliar lobes deltate to elliptic, $0.4-0.6 \times 0.3 \mathrm{~mm}$. Flowers 4 or 5 -merous; pedicel c. $0.5 \mathrm{~mm}$ long, minutely puberulous (hairs c. $0.1 \mathrm{~mm}$ long), bractlets $3-5$, alternate, \pm obdeltate, $0.4-0.6 \times 0.4-0.5 \mathrm{~mm}$, often splitting in fruit, each bractlet bearing $5-7(-10)$ colleters (narrowly cylindrical to narrowly conical, c. $0.3 \mathrm{~mm}$ long). Calyx (hypanthium) \pm obconical, $1.7-2 \times 1.2 \mathrm{~mm}$, smooth, puberulous like the pedicel; calyx limb truncate to slightly undulate, margin glabrous or minutely ciliate (hairs $\leq 0.1 \mathrm{~mm}$ long). Ovary: disc low domed to \pm discoid, entire. Corolla broadly funnel-shaped, $8-12 \times$ 12 - $15 \mathrm{~mm}$, smooth; corolla tube longer than the 
corolla lobes, 7 - $9 \mathrm{~mm}$ long; corolla lobes $5-7.4 \times 3-$ $3.9 \mathrm{~mm}$. Stamens: filaments c. $1.3 \mathrm{~mm}$ long; anthers 3.5 - $4.5 \mathrm{~mm}$ long. Style 10 - $12 \mathrm{~mm}$ long; stigma lobes c. $2.2 \mathrm{~mm}$ long. Fruit ellipsoid to ellipsoid-obovoid, 8 $9.4 \times 5-6 \mathrm{~mm}$, smooth (when dried), colour unknown, sparsely and minutely puberulous (hairs < $0.1 \mathrm{~mm}$ long); fruit wall thickness unknown; pedicel 3 - $5 \mathrm{~mm}$ long, puberulous (like the fruit); calyx limb indistinct, disc prominent. Seeds \pm elliptic in outline, c. $9 \times 6 \mathrm{~mm}$, c. $3.5 \mathrm{~mm}$ thick. Fig. $4 \mathrm{~A}$.

RECOGNITION. Coffea darainensis shares morphological similarities with C. littoralis A.P.Davis \& Rakotonas. (Davis \& Rakotonasolo 2001a), due to the leaves having $4-6$ secondary veins (with an open venation pattern), general inflorescence structure, and general flower and fruit morphology. Coffea darainensis can be separated from C. littoralis by the following morphological characteristics (characters for C. littoralis in square brackets): Leaves: petiole $0.5-0.7 \mathrm{~cm}$ long [vs $0.1-0.3 \mathrm{~cm}$ long], lamina obovate to broadly obovate, or obovate-elliptic, $3.5-5.6 \times(1-) 1.2-3 \mathrm{~cm}$, and coriaceous [vs broadly elliptic to broadly ovate, or \pm orbicular, $(1.4-) 1.9-3.5(-4.7) \times(1.4-) 1.9-2.8(-$ $3.3) \mathrm{cm}$, and subcoriaceous], base acute to attenuate [vs rounded to obtuse]; adaxial leaf surface: venation \pm invisible to manifest [vs venation prominent, more clearly manifest than the abaxial surface]; inflorescences: 1 or 2 per leaf axil, each inflorescence $3-5$ flowered, (3.2) $5-6.9 \mathrm{~mm}$ long, branched, and axis (part bearing calyculi) $2.9-5 \mathrm{~mm}$ long [vs 1 per leaf axil, each inflorescence 1-flowered, 3 - $5 \mathrm{~mm}$ long, unbranched, and axis $2-2.5 \mathrm{~mm}$ long].

DISTRIBUTION. Endemic to northern Madagascar and restricted to the forests of Loky Manambato Protected Area (Prov. Antsiranana; Region Sava; Distr. Vohimarina), and specifically to Forêt d'Ambohitsitondroina and Forêt d'Antsaharaingy. See Map 1 and Specimens Examined.

SPeCIMEnS eXamined. MAdAgASCAR. Prov. Antsiranana; Region Sava; Distr. Vohemar: sous-préfecture de Vohemar, commune rurale de Daraina, Daraina, Forêt d'Antsaharaingy, 90 m, 18 April 2004 (fr.), P. Ranirison PR 689 (G, K, P, MO, TEF).

HABITAT \& ECOLOGY. Seasonally dry (semi-deciduous) forest. Elevation 90 - $250 \mathrm{~m}$ above sea level.

CONSERVATION ASSESSMENT. Provisionally assessed as Critically Endangered (IUCN 2012). CR B2ab(iii). B2 area of occupancy (AOO) estimated to be less than $10 \mathrm{~km}^{2}\left(8 \mathrm{~km}^{2}\right.$ for $C$. darainensis, at a cell width of 2 $\mathrm{km} ; 2 \mathrm{~km}^{2}$ for $C$. darainensis, at a cell width of $1 \mathrm{~km}$ ); $\mathrm{a}$ - severely fragmented, with two locations; and b (iii) - continuing decline projected, in area, extent and/or quality of habitat. The AOO falls well within the limits for the CR category; even if several other subpopulations are found within the two locations, the AOO would still fall within this category. We designated a cell width of $1 \mathrm{~km}$ on the basis that the forest fragments in which this species occurs are less than $1 \mathrm{~km}$ wide. Coffea darainensis is only known from two collections representing one location (Antsaharaingy and Ambohitsitondroina forests in the Loky Manambato Protected Area).

PHENOLOGY. Imperfectly known - flowering in December; fruiting from January to April.

ETYMOLOGY. Coffea darainensis is named after the Daraina area in northern Madagascar.

NOTES. Coffea darainensis and C. littoralis are similar morphologically, although they are easy to separate on the size and texture of the leaves (see Recognition). Both species occur in the same general area of NE Madagascar (Prov. Antsiranana; Region Sava; Distr. Vohemar), but their distributions do not overlap: C. darainensis occurs inland in two parcels of forest within the western part of the Loky Manambato Protected Area, at an elevation of 90 $250 \mathrm{~m}$ above sea level; whereas $C$. littoralis is restricted to coastal regions (littoral forest) close to the town of Vohemar, at $0-25 \mathrm{~m}$ above sea level.

5. Coffea callmanderi A.P.Davis $\mathcal{E}$ Rakotonas., sp. nov. Type: Madagascar. Prov. Antsiranana; Region Diana; Distr. Ambanja: commune Beramanja, Kalabenono, bas de crête, 550 m, 25 Nov. 2007, (fl.), Callmander et al. 752 (holotype G [G001165658]!; isotypes K!, MO!, P!, TAN!).

http:/ /www.ipni.org/urn:lsid:ipni.org:names:77216862-1

Small tree, c. $3 \mathrm{~m}$ high, dbh unknown. Bark not recorded. Branches c. $6 \mathrm{~mm}$ in diam., \pm smooth, dark brown. Branchlets \pm terete to slightly flattened, c. $4 \mathrm{~mm}$ in diam., \pm smooth, dark brown, glabrous. Stipules semi-persistent to caducous, depressed ovate or \pm deltate, $2.7-4.2 \times 6.9-$ $9 \mathrm{~mm}$, chartaceous to subcoriaceous, glabrous; margin glabrous; apex acute, shortly apiculate, apiculum c. $1.5 \mathrm{~mm}$ long. Leaves: petiole $1.1-2.3 \mathrm{~cm}$ long, glabrous; lamina elliptic to obovate, or elliptic-ovate, $(9.5-) 15.8-$ $17.2 \times(4.8-) 5.8-8.3 \mathrm{~cm}$, subcoriaceous; base cuneate to narrowly cuneate, or attenuate, often decurrent; margins subrevolute to flat; apex obtuse to broadly acute, abruptly caudate, cauda $0.6-1.2 \mathrm{~cm}$ long; abaxial surface: secondary veins prominent, $(8-) 10-12$ pairs, with prominent intermediates (intersecondaries), ascending at an angle of $30^{\circ}-45^{\circ}$, tertiary venation rather prominent, \pm reticulate; higher order venation manifest to obscure, ramified; texture smooth; domatia ?absent, corky swellings with or without openings, axillary, against or on the midrib, orifice, c. $0.5 \mathrm{~mm}$ in diam., the margin and body rather corky, glabrous; adaxial surface: venation very prominent (more so than the abaxial surface); domatia invisible. Inflorescences interfoliar, 1 or 2 per leaf 
axil, each inflorescence 1 to 4-flowered, $9.8-10.2 \mathrm{~mm}$ long, unbranched or fasciculate, moderately covered in exudate; inflorescence axis (part bearing calyculi) 2.3 $2.5 \mathrm{~mm}$ long. Calyculi 3, nested within each other; glabrous, margins ciliate (hairs $0.1-0.2 \mathrm{~mm}$ long); basal (1st) calyculus c. $1.5 \times 2.5 \mathrm{~mm}$, lobes not seen; middle (2nd) calyculus c. $1.4 \times 2.2 \mathrm{~mm}$, lobes not seen; upper (3rd) calyculus c. $2.4 \times 3.5 \mathrm{~mm}$, lobes not seen. Flowers poorly known (only calyces seen); pedicel $2-2.5 \mathrm{~mm}$ long, glabrous, bractlets absent. Calyx (hypanthium) obconical to turbinate, $3.8-4.1 \times 4-4.2 \mathrm{~mm}$, texture smooth to slightly wrinkled (when dried), glabrous; calyx limb truncate to undulate, margin glabrous. Ovary: disc \pm discoid-tubular, 5-lobed. Corolla and other flower parts not seen. Fruit unknown. Seeds unknown.

RECOGNITION. Coffea callmanderi is somewhat similar to C. richardii J.-F.Leroy as both have large (usually more than $15 \mathrm{~cm}$ long and $6 \mathrm{~cm}$ wide) coriaceous leaves, with usually more than ten prominent secondary veins. These species are, however, easily set apart, on the basis of the following characters (those for C. richardii are given in square brackets): leaves elliptic to obovate, or elliptic-ovate, $(9.5-) 15.8-17.2 \times(4.8$ -) $5.8-8.3 \mathrm{~cm}$ [vs broadly elliptic to narrowly elliptic, oval to oval-ovate, or rarely oval-obovate, $17-23.5$ ($29) \times(5.2-) 7.4-13.5(-16.7) \mathrm{cm}]$; secondary veins $(8$ -) 10 - 12 pairs [vs $10-14$ (- 16) pairs; adaxial venation very prominent (more so than the abaxial surface) [vs venation manifest to rather obscure (less prominent than abaxial surface]; inflorescences 1 - 4flowered, 9.8 - $10.2 \mathrm{~mm}$ long [vs inflorescence 4-6 (8)-flowered, 8 - $11 \mathrm{~mm}$ long]; flower pedicel 2 $2.5 \mathrm{~mm}$ long [vs $0.1-0.5 \mathrm{~mm}$ long]; calyx (hypanthium) $3.8-4.1 \times 4-4.2 \mathrm{~mm}$ [vs $1.8-2.3 \times$ $2.8-3.2 \mathrm{~mm}]$.

DISTRIBUTION. Endemic to north-western Madagascar, near Ambanja (Prov. Antsiranana; Region Diana; Distr. Ambanja), only known from Kalobinono Mountain of the Galoko mountain range. See Map 1 and Specimens Examined.

SPECIMEN EXAMINED. MADAgASCAR. Prov. Antsiranana; Region Diana; Distr. Ambanja: Galoko Chain, lower slopes of Kalabenono, ridge just above village and Tavy, 630 m, 21 March 2009 (ster.), A. P. Davis E F. Rakotonasolo APD 4734 (K, TAN).

HABITAT \& ECOLOGY. Humid, evergreen forest within the Sambirano Region; on (Isalo) sandstone; altitude $550-630 \mathrm{~m}$.

CONSERVATION ASSESSMENT. Provisionally assessed as Critically Endangered (IUCN 2012). CR B2ab(iii). B2 area of occupancy (AOO) estimated to be less than $10 \mathrm{~km}^{2}\left(8 \mathrm{~km}^{2}\right.$ at a cell width of $2 \mathrm{~km} ; 2 \mathrm{~km}^{2}$, at cell width $1 \mathrm{~km})$; a - known to exist at only a single location; and b (iii) - continuing decline, observed, and projected, in area, extent and/or quality of habitat. The AOO falls well within the limits for the
CR category; even if several other subpopulations are found within the location and available forest area (which extends someway to the north), the AOO would still fall within the CR category. We designated a cell width of $1 \mathrm{~km}$ on the basis that the forest fragments in which this species occurs are less than $1 \mathrm{~km}$ wide. At the only known location for this species, there is an ongoing and drastic reduction of forest cover (which this species requires) due to agricultural expansion and human habitation (new settlements). The known distribution range of Coffea callmanderi falls within the Galoko-Kalobinono Protected Area.

PHENOLOGY. Imperfectly known - flowering in November; probably fruiting from December to February, and possibly March.

ETYMOLOGY. Coffea callmanderi is named after Martin W. Callmander, who discovered this species, coorganised the first collecting mission to the GalokoKalobinono mountainous area, and undertook considerable exploratory fieldwork in northern Madagascar.

NOTES. Coffea callmanderi is an intriguing species as it does not resemble any other species from northern Madagascar, but rather the large-leaved species from lowland eastern Madagascar, C. richardii J.-F.Leroy and C. farafanganensis J.-F.Leroy, particularly the former species. Despite the flowers being largely unknown and fruits not known, C. callmanderi is easily set apart from $C$. richardii on the basis of leaf and flower characteristics (see Recognition).

6. Coffea kalobinonensis A.P.Davis $\mathcal{E}$ Rakotanas., sp. nov. Type: Madagascar. Prov. Antsiranana; Region Diana; Distr. Ambanja: Beramanja, Anketrabe, village le plus proche Antanambao Belinta, versant nordouest du Kalabenono, sommet ouest de la grande falaise, 941 m, 29 Dec. 2007 (fr.), C. Rakotovao et al. 3843 (holotype G [G00192016]!; isotypes MO!, P!, TAN!).

http:/ /www.ipni.org/urn:lsid:ipni.org:names:77216864-1

Small tree, 4 - $6 \mathrm{~m}$ high, dbh c. $6 \mathrm{~cm}$. Bark browngrey, mottled, slightly rough. Branches $8-10 \mathrm{~mm}$ in diam., \pm smooth, dark brown. Branchlets \pm terete, 3 - $4 \mathrm{~mm}$ in diam., \pm smooth, dark brown, puberulous (hairs c. $0.05 \mathrm{~mm}$ long) on young shoots. Stipules caducous, depressed ovate or depressed ovate-truncate, $1.3-1.7 \times 1.4-1.6 \mathrm{~mm}$, subcoriaceous, puberulous like the young shoots; margin ciliate (hairs c. $0.1 \mathrm{~mm}$ long); apex broadly acute to very broadly acute. Leaves: petiole 0.7 $1.7 \mathrm{~cm}$ long, glabrous; lamina elliptic-obovate, or \pm obovate, or elliptic to broadly elliptic, $(5.5-) 8$ $10 \times(2.2-) 2.9-4.6 \mathrm{~cm}$, subcoriaceous; base 
narrowly cuneate, decurrent; margins subrevolute to flat; apex obtuse to broadly acute, very abruptly caudate, cauda $0.2-0.4 \mathrm{~cm}$ long; abaxial surface: secondary veins prominent, $6-8$ pairs, with prominent intermediates (intersecondaies), ascending at an angle of c. $45^{\circ}$, tertiary venation rather prominent, \pm reticulate; higher order venation manifest to obscure, ramified; texture smooth; domatia prominent, located in the axils of the secondary veins, against the midrib, orifice, $c$. $0.4 \mathrm{~mm}$ in diam., surrounding leaf tissue slightly swollen, glabrous or sparsely covered in small hairs (c. $0.05 \mathrm{~mm}$ long); adaxial surface: venation prominent; domatia obscure to manifest. Inflorescences interfoliar, 1 per leaf axil, each inflorescence 3 to 5-flowered, 8 - $9.8 \mathrm{~mm}$ long, shortly branched (1 or 2 orders of branching), mostly exudate free; inflorescence axis (part bearing calyculi) 3.8 $6.4 \mathrm{~mm}$ long. Calyculi 3, shortly stalked to stalked (stalks $0.4-0.6 \mathrm{~mm}$ long); glabrous, margins ciliate (hairs c. $0 . \mathrm{mm}$ long); basal (1st) calyculus $1.5-2.2$ $\times 2.2-2.7 \mathrm{~mm}$, stipular lobes ovate to depressed ovate, $0.9-1.2 \times 0.2-0.4 \mathrm{~mm}$, foliar lobes obovate, $0.2-0.4 \times 0.1-0.3 \mathrm{~mm}$; middle (2nd) calyculus c. $1.4 \times 2.1 \mathrm{~mm}$, stipular lobes $0.8-1.2 \times$ 0.3 , foliar lobes not seen; upper (3rd) calyculus c. $1.4 \times 2 \mathrm{~mm}$, stipular lobes c. $0.8 \times 0.3$, foliar lobes not seen. Flowers unknown. Fruit (immature) \pm ellipsoid, $9.5-10.2 \times 5-5.5 \mathrm{~mm}$, smooth (when dried), minutely pubescent (hairs c. $0.1 \mathrm{~mm}$ long). Seeds unknown.

RECOGNITION. Coffea kalobinonensis is similar to C. coursiana J.-F.Leroy, a species from the humid, evergreen forests of Eastern Madagascar, due to the overall appearance of leaves and by having multiflowered inflorescences. Even though C. kalobinonensis is imperfectly known, these species are, however, easily set apart, on the basis of the following characters (those for $C$. coursiana are given in square brackets): petioles $0.7-1.7 \mathrm{~cm}$ long [vs $0.2-$ $0.9 \mathrm{~cm}$ long], lamina $(5.5-) 8-10 \times(2.2-) 2.9-$ $4.6 \mathrm{~cm}$ [vs $3.5-7(-8.4) \times 1.8-3.5(-4.4) \mathrm{cm}$ ], subcoriaceous [vs chartaceous to subcoriaceous], with $6-8$ pairs of secondary veins [vs $4-6$ pairs]; fruit (only immature fruit seen), $9.5-10.2 \times 5-5.5 \mathrm{~mm}$ [vs $7-8.5 \times 4.3-4.5 \mathrm{~mm}$ ] and minutely pubescent [vs glabrous].

DISTRIBUTION. Endemic to north-western Madagascar, near Ambanja (Prov. Antsiranana; Region Diana; Distr. Ambanja), only known from Kalobinono Mountain of the Galoko mountain range. See Map 1 and Specimens Examined.

SPeCimens eXamined. MAdagascar. Prov. Antsiranana; Region Diana; Distr. Ambanja: Galoko Chain, lower slopes of Kalabenono, ridge just above village and tavy, $550 \mathrm{~m}$, 21 March 2009 (ster.), A. P. Davis
APD 4729 (K, TAN); loc. cit., 21 March 2009 (seedling; ster.), A. P. Davis APD 4731 (K, TAN); loc. cit., $630 \mathrm{~m}$, 21 March 2009 (partially ster.), A. P. Davis APD 4735 (K, TAN).

HABITAT \& ECOLOGY. Humid, evergreen forest within the Sambirano Region; on ridges; on (Isalo) sandstone; elevation 550 - $950 \mathrm{~m}$ above sea level.

CONSERVATION ASSESSMENT. Provisionally assessed as Critically Endangered (IUCN 2012). CR Blab(iii) $+2 \mathrm{ab}$ (iii). B1 - extent of occurrence (EOO) estimated to be less than $100 \mathrm{~km}^{2}\left(0.7 \mathrm{~km}^{2}\right.$ for Coffea kalobinonensis); a - known to exist at only a single location (one location for C. kalobinonensis); and b (iii) - continuing decline projected, in area, extent and/or quality of habitat. B2 area of occupancy (AOO) estimated to be less than $10 \mathrm{~km}^{2}\left(8 \mathrm{~km}^{2}\right.$ for C. kalobinonensis, at a cell width of $2 \mathrm{~km} ; 3 \mathrm{~km}^{2}$ at a cell width of $1 \mathrm{~km}$ ); a - known to exist at only a single location; and b (iii) - continuing decline, observed, and projected, in area, extent and/or quality of habitat. EOO and AOO fall well within the limits for the CR category; even if other subpopulations are found within the known location or surrounding areas, the limits of this category are unlikely to be breached. At the only known location for this species, there is an ongoing and drastic reduction of forest cover (which this species requires) due to agricultural expansion and human habitation (new settlements). The known distribution range of C. kalobinonensis falls within the GalokoKalobinono Protected Area.

PHENOLOGY. Imperfectly known - probably flowering from November to December; fruiting from late December, probably until March.

ETYMOLOGY. Coffea kalobinonensis is named after the Kalobinono Mountain in north-western Madagascar, a location with a high number of endemics and considerable biodiversity.

NOTES. Coffea kalobinonensis resembles a larger variant of $C$. coursiana, but these species are easily separated on the basis of several morphological differences (see Recognition). Coffea kalobinonensis is restricted to the Kalabinono mountain area of north-western Madagascar (Sambirano region), at 550 - $950 \mathrm{~m}$, whereas C. coursiana occurs in the humid, evergreen forests of Eastern Madagascar (usually at $400-500 \mathrm{~m}$ ).

\section{Acknowledgements}

We gratefully acknowledge the co-operation of the following organisations and ministries in Antananarivo, Madagascar: Association National pour la Gestion des Aires Protégées (ANGAP), Ministère des Eaux et Forêts (MEF), Ministère de la Recherche Scientifique Centre National de Recherche Appliquée au Développement Rural (FOFIFA). We also offer our sincere thanks to: the herbaria of $\mathrm{G}, \mathrm{K}$, 
MO, P, TAN and TEF for the loan or use of material for this study; Martin Callmander and Louis Nusbaumer for providing assistance with fieldwork logistics, and for various resources and guidance used in the production of this contribution; Louis Nusbaumer and Patrick Ranirison for the use of field images; and Lucy T. Smith for providing the line drawings of Coffea.

Open Access This article is licensed under a Creative Commons Attribution 4.0 International License, which permits use, sharing, adaptation, distribution and reproduction in any medium or format, as long as you give appropriate credit to the original author(s) and the source, provide a link to the Creative Commons licence, and indicate if changes were made. The images or other third party material in this article are included in the article's Creative Commons licence, unless indicated otherwise in a credit line to the material. If material is not included in the article's Creative Commons licence and your intended use is not permitted by statutory regulation or exceeds the permitted use, you will need to obtain permission directly from the copyright holder. To view a copy of this licence, visit http://creativecommons.org/ licenses/by/4.0/.

\section{References}

Bachman, S., Moat, J., Hill, A., Torre, J. de \& Scott, B. (2011). Supporting Red List threat assessments with GeoCAT: geospatial conservation assessment tool. ZooKeys 126: 117 - 126.

Callmander, M. W., Buerki, S. \& Wohlhauser, S. (2008). A new threatened species of Pandanaceae from northwestern Madagascar, Pandanus sermolliana. Novon 18: 421.

Phillipson, P. B. \& Lowry II, P. P. (2012). Novelties from the Northern Mountains Complex of Madagascar. III. Two new species of Turraea L. (Meliaceae). Adansonia, sér. 3, 34: 93 - 102.

, Andriamahefarivo, L. D. \& Lowry II P. P. (2018). Flora. Site 10. Galoko-Kalobinono. In: S. M. Goodman, M. J. Raherilalao \& S. Wohlhauser (ed.), The terrestrial protected areas of Madagascar: their history, description, and biota, pp. 589 - 593. Association Vahatra, Antananarivo.

Rakotovao, C., Razafitsalama, J., Buerki, S., Hong-Wa, C., Rakotoarivelo, N., Andriambololonera, S., Koopman, M., Johnson, D., Deroin, T., Andriamandranto, R., Solo, S., Phillipson, P. B., Labat, J.-N. \& Lowry II, P. P. (2009). New species from the Galoka and Kalabenono massifs: two unknown and severely threatened mountainous areas in NW Madagascar. Candollea 64: 179 - 202.
, Razakamalala, R., Luino, I., Andriamarisoa, R. \& Buerki, S. (2020). Novelties from the Northern Mountains Complex of Madagascar V: A new threatened Pandanus (Pandanaceae) from the Kalobinono massif. Candollea 75: 99 - 105. https://doi.org/10.15553/c2020v751a10.

Davis, A. P. (2011). Psilanthus mannii, the type species of Psilanthus, transferred to Coffea. Nord. J. Bot. 29: $471-472$.

, Bridson, D. M. \&. Rakotonasolo, F. (2005). A reexamination of Coffea subgenus Baracoffea and comments on the morphology and classification of Coffea and Psilanthus (Rubiaceae-Coffeeae). In: R. C. Keating, V. C. Hollowell \& T. Croat (eds), A festschrift for William G. D'Arcy: the legacy of a taxonomist. Monogr. Syst. Bot. 104: 398 - 420. MBG Press, Missouri.

, Chadburn, H., Moat, J., O’Sullivan, R., Hargreaves, S. \& Nic Lughadha, E. (2019). High extinction risk for wild coffee species and implications for coffee sector sustainability. Sci. Adv. 5: eaav3473. https://doi.org/10.1126/sciadv.aav3473.

Chester, M., Maurin, O. \& Fay, M. F. (2007). Searching for the relatives of Coffea (Rubiaceae, Ixoroideae): the circumscription and phylogeny of Coffeeae based on plastid sequence data and morphology. Amer. J. Bot. 94: 313 - 329.

Govaerts, R., Bridson, D. M. \& Stoffelen, P. (2006). An annotated taxonomic conspectus of the genus Coffea (Rubiaceae). Bot. J. Linn. Soc. 152: 465 -512 .

\& Rakotonasolo, F. (2001a). Three new species of Coffea L. (Rubiaceae) from NE Madagascar. Adansonia, sér. 3, 23: 137 - 146.

\& _ (2001b). Two new species of Coffea L. (Rubiaceae) from Northern Madagascar. Adansonia, sér. 3, 23: 337 - 345.

\& _ (2008). A taxonomic revision of the baracoffea alliance: nine remarkable Coffea species from western Madagascar. Bot. J. Linn. Soc. 158: 355 -390 .

\& De Block, P. (2010). Coffea toshii sp. nov. (Rubiaceae) from Madagascar. Nord. J. Bot. 28: 134 -136 .

, Tosh, J., Ruch, N. \& Fay, M. F. (2011). Growing coffee: Psilanthus (Rubiaceae) subsumed on the basis of molecular and morphological data; implications for the size, morphology, distribution and evolutionary history of Coffea. Bot. J. Linn. Soc. 167: $357-377$.

Gautier, L., Ranirison, P., Nusbaumer, L. \& Wohlhauser, S. (2006). Aperçu des massifs forestiers de la région Loky-Manambato. In: S. M. Goodman \& L. Wilmé (ed.), Inventaires de la faune et de la flore du Nord de Madagascar dans la région Loky-Manambato, Analamerana et Andavakoera, pp. 81 - 99. CIDST, Ministère de 
l'Education Nationale et de la Recherche Scientifique, Antananarivo.

Goodman, S. M., Raherilalao, M. J. \& Wohlhauser, S. (eds) (2018). The terrestrial protected areas of Madagascar: their history, description, and biota. Association Vahatra, Antananarivo.

Holmgren, P. K., Holmgren, N. \& Barnett, L. C. (1990). Index Herbariorum. Part 1: The Herbaria of the World, 8th edn. Regnum Vegetabile. New York Botanical Garden.

IUCN (2012). IUCN Red List Categories and Criteria: Version 3.1. Second edition. IUCN Species Survival Commission, Gland and Cambridge. https://portals.iucn.org/library/sites/library/files/documents/RL-2 001-001-2nd.pdf. Accessed 30 April 2020.

IUCN [Standards and Petitions Subcommittee] (2019). Guidelines for using the IUCN Red List Categories and Criteria. Version 14. Prepared by the Standards and Petitions Subcommittee.https://nc. iucnredlist.org/redlist/content/attachment_files/ RedListGuidelines.pdf

Maurin, O., Davis, A. P., Chester, M., Mvungi, E. F., Jaufeerally-Fakim, Y. \& Fay, M. F. (2007). Towards a phylogeny for Coffea (Rubiaceae): identifying wellsupported lineages based on nuclear and plastid DNA sequences. Ann. Bot. 100: 1565 - 1583.

Moat, J. \& Smith, P. (2007). Atlas of the Vegetation of Madagascar. Royal Botanic Gardens, Kew.

Nusbaumer, L., Ranirison, P., Gautier, L., Chatelain, C., Loizeau, P.-A. \& Spichiger, R. (2010). Loky-Manambato: point de rencontre des principales unités phytogéographiques de Madagascar. In: X. Van Der Burgt et al. (ed.), Systématique et conservation des plantes Africaines, pp. 253 - 264. Royal Botanic Gardens, Kew.

Phillipson, P. B., Andriamahefarivo, L. D., Gautier L. \& Lowry II, P. P. (2018). Flora. Site 6. Loky Manambato. In: S. M. Goodman, M. J. Raherilalao \& S. Wohlhauser (eds), The terrestrial protected areas of Madagascar: their history, description, and biota, pp. 534 - 536. Association Vahatra, Antananarivo.

Randrianasolo, A. \& Lowry II, P. P. (2009). Four new species and one new combination in the Malagasy endemic genus Micronychia Oliv. (Anacardiaceae). Adansonia, sér. 3, 31: 157 - 168.

Ranirison, P., Andriamiarantsoa, Y., Gautier, L. \& Wohlhauser, S. (2018). Vegetation. Site 6. Loky Manambato. In: S. M. Goodman, M. J. Raherilalao \& S. Wohlhauser (eds), The terrestrial protected areas of Madagascar: their history, description, and biota: pp. 532 - 534. Association Vahatra, Antananarivo.

Schatz, G. E. \& Lowry II, P. P. (2020). Taxonomic studies of Diospyros L. (Ebenaceae) from the Malagasy region. IV. Synoptic revision of the Squamosa group in Madagascar and the Comoro Islands. Adansonia, sér. 3, 42: $201-218$.

Shorthouse, D. P. (2010). SimpleMappr, an online tool to produce publication-quality point maps. www. simplemappr.net. Accessed 1 March 2020.

Tahinarivony, J. A. \& Callmander, M. W. (2018). Vegetation. Site 10. Galoko-Kalobinono. In: S. M. Goodman, M. J. Raherilalao \& S. Wohlhauser (eds), The terrestrial protected areas of Madagascar: their history, description, and biota, pp. 587 - 589. Association Vahatra, Antananarivo

Thiers, B. M. (2020). Index Herbariorum: A Global Directory of Public Herbaria and Associated Staff. New York Botanical Garden's Virtual Herbarium. http://sweetgum.nybg.org/science/ih/. Accessed 30 April 2020.

Wahlert, G. A. (2016). Novelties from the Northern Mountains Complex of Madagascar IV: A new Rinorea Aubl. (Violaceae) of restricted range from the Galoko and Kalabinono massifs. Candollea 71: $205-210$.

Willis, F., Moat, J. \& Paton, A. (2003). Defining a role for herbarium data in red list assessments: a case study of Plectranthus from eastern and southern tropical Africa. Biodiv. Conserv. 12: 1537 - 1552.

\section{Publisher's Note}

Springer Nature remains neutral with regard to jurisdictional claims in published maps and institutional affiliations. 